\title{
PRINCIPLES OF THE PROPOSED CZECH POSTAL SECTOR PRICE CONTROL MODEL
}

\begin{abstract}
The paper deals with the postal sector control. It results from the control theory and proves the justifiability of control in the postal sector. Within the price control it results from EU Directive $97 / 67 / E C$ requirements on this control and states individual types of price control focusing on ineffective price control currently used in the Czech postal sector (especially within domestic services) and proposes a more effective method of price control. The paper also discusses the principles of the proposed method of price control of the Czech postal sector. It describes concrete fulfilment of the price control model resulting from the price-cap and tariff formula RPI-X and concentrates on its quantitative expression. The application of the proposed model is carried out for a hypothetical period in the past (in order to compare it with the current control system) for letter items tariff basket.
\end{abstract}

\section{KEY WORDS}

control, prices, postal services, price-cap, Czech Post, model

\section{INTRODUCTION}

It is necessary to understand the postal sector control as a subset of overall government control, which is applied especially for the reason of possibility of correcting significant market failures, the causes of which are deformed prices, quantities and incomes. These market failures or, if you like, imperfect competition, arise especially when the sector output is offered by a small number of firms. There are two main sources of imperfect competition, the cost conditions (especially economies of scale and scope) and competition barriers (patents, licences, product differentiation etc.) [1].

Postal sector is an example of this imperfect competition due to the existing economies of scale and scope (cost conditions), with which the postal sector comes near to the theoretical market situation - extreme natural monopoly. In the postal sector there are also still the competition barriers (reservation of specific, exactly defined, range of postal services to the only provider - postal licence holder - as compensation for the provision of universal (basic) postal services ${ }^{1}$. In addition, there is also the market social aspect in the postal sector (state obligation to ensure accessible "basic" postal services for the inhabitants). For these reasons it is evident that the Czech postal sector control is unavoidable under the current conditions.

There is again the possibility of understanding the postal sector price control as a subset of overall postal sector control and it is possible to define the postal sector price control as determination or direct control of the price level by the price body and local authority.

The Act of the Czech Republic No. 526/1990 Coll. on prices as amended emphasises the following: "In cases when the market is threatened by the effects of competition constraints or it is necessary due to extraordinary market situation, the state administration bodies can regulate the price formation under this act." 2

The price control in the postal sector is carried out partly by the Ministry of Finances (further in the text: MF) for domestic services and by the Czech Telecommunication Office (further in the text: $\mathrm{CZO}$ ) for international services ${ }^{3}$.

\section{POSTAL SECTOR PRICE CONTROL REQUIREMENTS}

Directive 97/67/EC of the European Parliament and of the Council on common rules for the development of the internal market of Community postal services and the improvement of quality of service (further in the text: Postal Directive) as a fundamental rule of law relating to the European postal sector sets out the control of prices of universal postal service requirements in Articles 3 and 12.

Article 12 provides that "for each of the services forming part of the provision of the "universal service" prices must be "affordable", "geared to costs", and "transparent and non-discriminatory". By the way of limited exception to the principle of cost-based pricing, a member state may require that a postage rate be 
Table 1 - Scope and methods of price control in the EU

\begin{tabular}{|c|c|c|c|c|c|c|}
\hline Country & NRA & Scope of price control & $\begin{array}{c}\text { Ex } \\
\text { ante }\end{array}$ & $\begin{array}{c}\text { Price } \\
\text { cap }\end{array}$ & $\begin{array}{c}\text { Ex } \\
\text { post }\end{array}$ & $\begin{array}{c}\text { Cost } \\
\text { based }\end{array}$ \\
\hline AT & Rundfunk und Telekom Regulierungs & Reserved, USO & $\mathrm{x}$ & & $\mathrm{x}$ & $\mathrm{x}$ \\
\hline $\mathrm{BE}$ & $\begin{array}{l}\text { Belgian Institute for Post service and } \\
\text { Telecommunications }\end{array}$ & Reserved, USO, Other & & $\mathrm{x}$ & $\mathrm{x}$ & $\mathrm{x}$ \\
\hline BG & $\begin{array}{l}\text { Communications to Communications Regulation } \\
\text { Commission }\end{array}$ & Reserved, USO & & & & \\
\hline $\mathrm{CY}$ & $\begin{array}{l}\text { Office of the Commissioner of Telecommunications } \\
\text { and Postal Regulation }\end{array}$ & Reserved, USO, Other & $\mathrm{x}$ & $\mathrm{x}$ & $\mathrm{x}$ & $\mathrm{x}$ \\
\hline $\mathrm{CZ}$ & Czech Telecommunication Office Ministry of finance & Reserved, USO & $\mathrm{x}$ & & & $x$ \\
\hline $\mathrm{DE}$ & Bundesnetzagentur & USO, Other & $x$ & $\mathrm{x}$ & & \\
\hline DK & Fćrdselsstyrelse & Reserved, USO & $\mathrm{x}$ & $\mathrm{x}$ & 8 & $\mathrm{x}$ \\
\hline EE & Estonian Competition Authority & Reserved, USO & $\mathrm{x}$ & & & $\mathrm{x}$ \\
\hline ES & Ministerio de Fomento & Reserved, USO & $x$ & & $\mathrm{x}$ & $\mathrm{x}$ \\
\hline FI & Finnish Communications Regulatory Authority & USO & & & $\mathrm{x}$ & $\mathrm{x}$ \\
\hline FR & $\begin{array}{l}\text { Autorité de Régulation des Communications } \\
\text { Electroniques et des Postes }\end{array}$ & Reserved, USO & $\mathrm{x}$ & $\mathrm{x}$ & $\mathrm{x}$ & $\mathrm{x}$ \\
\hline GR & National Telecommunications and Post Commission & Reserved, USO & $\mathrm{x}$ & & & $\mathrm{x}$ \\
\hline $\mathrm{HU}$ & National Communications Authority & Reserved & $\mathrm{x}$ & $\mathrm{x}$ & & \\
\hline IE & Commission for Communications Regulation & Reserved, USO & $\mathrm{x}$ & & $\mathrm{x}$ & $\mathrm{x}$ \\
\hline IT & Ministry of Communications & Reserved, USO & $\mathrm{x}$ & $\mathrm{x}$ & $\mathrm{x}$ & \\
\hline LT & Communications Regulatory Authority & Reserved, USO & & $\mathrm{x}$ & $\mathrm{x}$ & $\mathrm{x}$ \\
\hline LU & Institut Luxembourgeois de Régulation & Reserved & $\mathrm{x}$ & $\mathrm{x}$ & & $\mathrm{x}$ \\
\hline LV & Public Utilities Commission & Reserved, USO & $\mathrm{x}$ & & & $\mathrm{x}$ \\
\hline MT & Malta Communications Authority & Reserved, USO & $\mathrm{x}$ & & & $\mathrm{x}$ \\
\hline NL & Onafhankelijke Post- en Telecommunicatie Autoriteit & Reserved, USO & $\mathrm{x}$ & $\mathrm{x}$ & & \\
\hline OPL & Office of Electronic Communications & Reserved, USO & $\mathrm{x}$ & & & $\mathrm{x}$ \\
\hline PT & Autoridade Nacional de Comunicaçőes & Reserved, USO & $\mathrm{x}$ & & $\mathrm{x}$ & $\mathrm{x}$ \\
\hline RO & $\begin{array}{l}\text { National Regulatory Authority for Communications } \\
\text { and Information Technology }\end{array}$ & Reserved, USO & $\mathrm{x}$ & & & $\mathrm{x}$ \\
\hline SI & Post and Electronic Communications Agency & Reserved, USO & $\mathrm{x}$ & & & $\mathrm{x}$ \\
\hline SE & Post- och telestyrelsen & USO & $\mathrm{x}$ & $\mathrm{x}$ & $x$ & $\mathrm{x}$ \\
\hline SK & Postal Regulatory Office & Reserved, USO & $\mathrm{x}$ & & & $\mathrm{x}$ \\
\hline UK & Postal Services Commission & USO, Other & $\mathrm{x}$ & $\mathrm{x}$ & & $\mathrm{x}$ \\
\hline
\end{tabular}

Source: Ecorys 2008

applied uniformly throughout the national territory. While Universal service providers (further in the text: USP) may conclude individual rate agreements with mailers, special or individualized tariffs must conform to the foregoing principles. Specifically, special tariffs for large businesses or companies which consolidate the mail of smaller firms should take account of the avoided costs, as compared to the standard service and shall apply equally both as between different third parties and as between third parties and USPs supply- ing equivalent services. Moreover, special tariffs must be made available to private customers who send post under similar conditions. Finally, Article 12 explicitly bars cross-subsidization of non-reserved services from revenues earned from reserved services "except to the extent to which it is shown to be strictly necessary to fulfil specific universal service obligations imposed in the competitive area".

It is evident that the Postal Directive sets out only general requirements and it does not deal with the 
concrete requirements on price control method. Consequently, the methods of price control implementation in individual EU member states are different.

The scope and methods of price control in the EU are presented in Table 1. It appears that in the most of the EU countries price control encompasses reserved services and universal services.

The Directive leaves to member states the choice of how to regulate the prices. The method preferred by the member states is ex ante control, i. e., the USP must obtain specific approval of the NRA before prices are changed. Twelve member states (BE, CY, DE, DK, FR, HU, IT, LT, LU, NL, SE, UK) appear to have instituted price cap regimes according to which the USP is free to adjust some or all regulated prices without specific approval of the regulator provided prices remain below the maximum level.

The Act of the Czech Republic No. 29/2000 Coll. on postal services as amended (fundamental rule of law relating to the Czech postal sector) refers to the above mentioned Act No. 526/1990 Coll. on prices in the context of price control. Also this act sets out that the prices of the basic services, which come under the postal obligation, have to result from economically justified costs associated with the provision of such services (in \$34a). Prices of these services have to be also generally acceptable, accessible for all the interested persons and they have to be set transparently. Finally, there is a ban on cross-subsidization of non-reserved services from revenues earned from reserved services.

\section{METHOD OF PRICE CONTROL USED IN THE CZECH POSTAL SECTOR}

The current method of price control of domestic services used in the Czech postal sector (see Table 1) is not suitable either for USP or postal service users.

There are some disadvantages:

- for USP - the prices are not in their competence and it lies "de facto" at the mercy of MF and their price decisions (often with some political context);

- for postal service users - they similarly have to rely on one-off decisions of MF without any transparent relation to the general price development in the Czech Republic.

\section{PROPOSED METHOD OF PRICE CONTROL OF THE CZECH POSTAL SECTOR}

Whichever the proposed method of price control of the Czech postal sector it should respect the following requirements:

- ensuring the provision of the universal service at affordable tariffs,
- furthering the interests of postal users wherever appropriate by promoting effective competition,

- encouraging efficiency and economy of the USP,

- having regard for the need to ensure that USP (licence holder) can finance their licensed activities,

- transparency,

- avoidance of perverse incentives.

Complying with the above mentioned requirements, the optimal method of price control of the Czech postal sector seems to be the price-cap control with tariff formula $R P I-X$, where RPI is the factor taking into account the inflation and $\mathrm{X}$ is a motivation factor taking into account, for example, the need of investment. This formula takes into account the development of the relevant input factors, with the coverage of the price control according to the result of competitive environment test (apparently comprising nearly all universal services provided by the Czech Post) and with two - five years control period. Concrete fulfilment of the proposed price-cap control model can be found in [2].

\subsection{Proposed price control model}

The proposed price control model is based on the price-cap control with tariff formula $R P I-X$, with coverage according to the result of the competitive environment test and with two years control period.

Initial for this method of price control is the dismemberment of controlled services into the so-called price baskets, namely:

a) letter items and valuable letter items including their complementary services,

b) parcels including their complementary services,

c) postal orders including their complementary services,

d) other obligatory services.

Each of these tariff baskets is extra monitored, and so there would be no cross subsidies among them,i. e. each of these price baskets fully covers his allocated costs.

Price regulation within baskets $\mathrm{a}, \mathrm{b}, \mathrm{c}$ has to meet these fundamentals:

- the regulation has to take into account the total price of the tariff basket,

- the regulation has to take into account the input changes,

- price changes will be realized on dates defined in advance.

\subsection{Tariff baskets and their price-caps}

As a matter of fact, the National regulation authority (further in the text: NRA) defines for each basket 
individual price-cap based on the resulting estimated revenues. Thus, the Czech Post management has full competency to set prices for particular weight step of items (based on its marketing experience) and their interrelated services in a particular basket. There is the possibility of defining one fixed price (if needed), for example, for letter items up to $20 \mathrm{~g}$. Thus, the management will not be allowed to ensure for themselves such a high revenue from the most common weight step $(20 \mathrm{~g})$ of a particular basket, and the management will not be forced to undertake any active price policy in other weight steps of a particular tariff basket.

Price regulation within tariff basket $\mathrm{d}$ will be enforced only if needed and the form will be the maximum prices.

Each of the tariff baskets a, b, c involves all the particular services and the frequency of individual services in the basket responds to the real frequency during the period of one year.

\subsection{Calculation principles of price-cap and periodicity of its setting}

It is necessary to calculate the level of price-cap for the expected reality in the half of the period, when the price-cap is in force, i. e. there is the necessity to estimate (based on the development in the past) the rate of inflation and further relevant characteristics similarly to how the price-cap would be defined in the half of the period. In this way the Czech Post has the benefit in the first half of the control period when it profits from the difference between the inflation and the value of other characteristics at the beginning of the period and halfway through the period, whereas in the second half of the period the Czech Post is emasculated. So the motivation of this price-cap method lies in the fact that there is scope for the management of the Czech Post to mobilize its activities (the Czech Post has higher revenues without any effort in the first half of the period) to do some rationalization actions, to increase labour productivity (etc.) in order to be able to get profit in the second half of the period as well. So it means that the acquired company's profit even creates the scope for the price reduction.

This method does not exclude cancellation of the already set price-cap in case of extreme inflation accumulation and sets the new one within the same principles.

\subsection{Calculation of the price-cap}

The base is to set the initial price-cap of tariff basket $P_{0}$ on the basis of the Czech Post cost calculation of individual services included in the relevant basket. At first, it is useful to do an audit by independent auditory company, which would investigate both objective affiliation of common costs to individual regulated and unregulated services and justifiability of the showed costs. The audit should assure fair-minded setting of the above mentioned initial price-cap.

This initial price-cap $P_{0}$ of individual tariff baskets will be verified by tariff formula (1) in two-year intervals.

The new total price of individual tariff basket (there is a basket of letter items as a model in this paper) within the Czech Republic postal sector is established in the following way:

$P_{1}=P_{0} *\left(I_{i}-X\right)$

where

$I_{i}=\left(a_{s c} * I_{s c}\right)+\left(a_{c o p s} * I_{c o p s}\right)+\left(a_{c p v} * I_{c p v}\right)+$

$+\left(a_{c t} * I_{c t}\right)+\left(a_{c v n d} * I_{c v n d}\right)+\left(a_{c p o} * I_{c p o}\right)+a_{0}$

$P_{0}$ - original price of tariff basket,

$P_{1}-$ new price of tariff basket,

$X$ - decision-making factor - range from 0 to 0.04 ,

$I_{i}$ - input inflation index,

$I_{s c}$ - customer price index,

$I_{\text {cops }}$ - other business services price index,

$I_{c p v}$ - industrial producer price index,

$I_{c t}$ - telecommunication price index,

$I_{c v n d}-$ domestic freight transport price index,

$I_{c p o}$ - insurance price index,

$a_{s c}-$ take of personal costs on total costs,

$a_{\text {cops }}$ - take of costs on other business services on total costs,

$a_{c p v}$ - take of costs of purchase from industrial producer on total costs,

$a_{c t}-$ take of costs of telecommunication services purchase on total costs,

$a_{\text {cvnd }}-$ take of costs of transport services purchase from external companies on total costs,

$a_{c p o}-$ take of costs of car and property insurance on total costs,

$a_{0}$ - take of costs exempt from inflation on total costs.

NRA fix the level of decision-making factor $X$ in particular on the basis of judgment of investment necessary and the possibility of its funding by productivity increase. Its (factor $X$ ) allowed range should be between 0 and $4 \%$ (for a two-year period), which is in compliance with the range of analogical factor used in the formula for the telecommunication sector. This factor motivates the company to increase the demand for its services, which is crucial for setting the prices in the postal sector.

Price increase means transmission of inflation impact to relevant inputs, which is evident from Equations 1 and 2 . The inflation impact is specified by way of the weighted average of the inflation index of individual cost group. 
The construction of input inflation index $I_{i}$ results from the concept of taking into account the relevant costs of the Czech Post, which has crucial impact on the resulting price of the regulated postal services.

The dynamic and transparent relevant costs monitoring is ensured by linking individual cost groups to accessible price indices, i. e. to suitable price indices monitored by the Czech Statistical Office (further in the text: CSO).

At first, the costs (respective cost groups) have to be set, which have significant impact on the resulting price of the regulated postal services. These cost groups are set based on the analysis of the economic activity statement of the Czech Post and price indices (monitored by CSO) judgment. Then the cost groups are linked to selected CSO monitored price indices.

Personal costs are the most important expense item, which has significant impact on the resulting price (more than $60 \%$ on total costs), which is evident from the character of postal services. Personal costs are then linked to the customer price index $I_{S C}$

Other costs that have crucial impact on the resulting price of regulated postal services (in compliance with the classification and contents of CSO price indices) are:

- costs on other business services,

- costs of purchase from industrial producer,

- costs of telecommunication services purchase,

- costs of transport services purchase from external companies,

- costs of car and property insurance,

- costs exempt from inflation.

These cost groups are linked to the below mentioned price indices:

- customer price index,

- other business services price index,

- industrial producer price index,

- telecommunication price index,

- domestic freight transport price index,

- insurance price index.

The calculation of coefficients $a_{s o} a_{c o p s} a_{c p v} a_{c b}$ $a_{\text {cvnd }}, a_{\text {cpo }} a_{0}$, (coefficients reflect the cost structure of the Czech Post) results from the Czech Post expense data (economic activity statement). The calculation of indices $I_{s o} I_{c o p s} I_{c p v}, I_{c v} I_{c v n d}, I_{c p o}$ i. e. the calculation of their average values in the determined period results from the time series of individual price indices monitored by CSO.

The principle of $a_{s o} a_{c o p s} a_{c p v}, a_{c b} a_{c v n d}, a_{c p o} a_{0}$ coefficient values setting and values of input inflation index $I_{i}$ setting will be illustrated by model calculation of $I_{i}$ for a hypothetical control period from 1 June of the year $n$ till 31 May of the year $n+2$ from the past. This hypothetical control period from the past was chosen because of the possibility to compare the real development of prices of the Czech Post regulated services with the price development according to the proposed model.

The values of $a_{s o} a_{c o p s}, a_{c p v}, a_{c b} a_{c v n d}, a_{c p o}, a_{0}$ coefficient are set on the basis of the appropriate Czech Post foundations. But first, there is the need to adjust the total cost by the amounts, which are not related to the regulated services, i. e. extraordinary costs, financial expenses and goods sold. Thus, for the abovementioned hypothetical period total adjusted cost is considered in an amount of $13,400,779$ thousand Czech crowns (as an illustration, it is the real figure from the year 2003).

For example, the principle of coefficient $a_{s c}$ setting is shown in Table 2.

\section{Table 2 - Coefficient $\mathbf{a}_{\mathrm{sc}}$ setting}

\begin{tabular}{|l|c|}
\hline Decisive costs for coefficient $\mathrm{a}_{\text {sc }}$ setting & $\begin{array}{c}\text { Amount } \\
\text { (thous. CZK) }\end{array}$ \\
\hline salaries, wages & $6,119,736$ \\
social and health insurance & $2,390,384$ \\
other & 1,454 \\
\hline total cost (personnel cost) & $8,511,574$ \\
\hline total adjusted cost & $13,400,779$ \\
\hline $\mathrm{a}_{\text {sc }}=$ total cost / total adjusted cost & 0.6352 \\
\hline
\end{tabular}

Source: Czech Post statement of cost

The values of other coefficients $a_{c o p s} a_{c p v} a_{c b}$ $a_{\text {cvnd }} a_{\text {cpo }}, a_{0}$ are shown in Table 3.

Table 3 - Values of the coefficients $\mathbf{a}_{\text {cops }}, \mathbf{a}_{\mathrm{cpv}}, \mathbf{a}_{\mathrm{ct}}, \mathbf{a}_{\mathrm{cvnd}}$, $\mathbf{a}_{\text {cpo }}, \mathbf{a}_{0}$

\begin{tabular}{|c|c|}
\hline Coefficient & Value \\
\hline \hline$a_{c o p s}$ & 0.1231 \\
\hline$a_{c p v}$ & 0.0850 \\
\hline$a_{c t}$ & 0.0374 \\
\hline$a_{c v n d}$ & 0.0076 \\
\hline$a_{c p o}$ & 0.0032 \\
\hline$a_{0}$ & 0.1085 \\
\hline
\end{tabular}

For example the principle of index $I_{s c}$ value calculation for the determined period is shown in Table 4. This index is calculated for the period from 1 June of the year n-1 till 31 May of the year $n+1$, which is in compliance with principles of the price-cap calculation (see Chapter 4.4).

Index $I_{s c}$ development within the period from 1 June of the year n-1 till 31 May of the year $n+1$ is graphically presented in Figure 1 (as an illustration it is based on the real data from the period 2000-2002). There is evident progression of index $I_{s c}$ within the monitored period. Indices $I_{c o p s} I_{c v n d}$ and $I_{c p o}$ have similar shape of the curve as index $I_{s c}$, whereas index 
$I_{c t}$ declines with certain fluctuations within the whole period. The presumed causes of index $I_{c t}$ falling (within the monitored period) are partly the keen competition in the telecommunication sector and partly the economies of scale as consequence of the increasing demand for telecommunication services. In regard to index $I_{c p v}$ there is only slight price growth within the monitored period.

Table 4 - Index $\mathbf{I}_{\mathrm{sc}}$ value calculation

\begin{tabular}{|c|c|c|}
\hline Year & Month & $\mathrm{I}_{\mathrm{Sc}}(\%)$ \\
\hline \multirow{7}{*}{$\mathrm{n}-1$} & June & 99.8 \\
\hline & July & 100.4 \\
\hline & August & 100.6 \\
\hline & September & 100.6 \\
\hline & October & 100.9 \\
\hline & November & 101.0 \\
\hline & December & 101.2 \\
\hline \multirow{12}{*}{$\mathrm{n}$} & January & 103.1 \\
\hline & February & 103.1 \\
\hline & March & 103.2 \\
\hline & April & 103.6 \\
\hline & May & 104.2 \\
\hline & June & 105.2 \\
\hline & July & 106.3 \\
\hline & August & 106.1 \\
\hline & September & 105.3 \\
\hline & October & 105.3 \\
\hline & November & 105.2 \\
\hline & December & 105.3 \\
\hline \multirow{5}{*}{$\mathrm{n}+1$} & January & 106.9 \\
\hline & February & 107.1 \\
\hline & March & 107.0 \\
\hline & April & 106.9 \\
\hline & May & 106.8 \\
\hline \multicolumn{2}{|c|}{ Average } & 103.9625 \\
\hline \multicolumn{2}{|c|}{ Value of index $I_{\mathrm{sc}}$} & 1.0396 \\
\hline
\end{tabular}

Note: The average value of $\mathrm{n}-1$ year is used as reference value

The values of other calculated indices $I_{c o p s} I_{c v n d}$ $I_{c p o}, I_{c b} I_{c p v}$ are shown in Table 5

The real values of coefficients $a_{s o} a_{c o p s} a_{c p v} a_{c b}$ $a_{c v n d}, a_{c p o}, a_{0}$ and indices $I_{s o} I_{c o p s}, I_{c p v}, I_{c b} I_{c v n d}, I_{c p o}$ have been established according to the equation (2):

$$
\begin{gathered}
I_{i}=(0.6352 * 1.0396)+(0.1231 * 1.0200)+ \\
+(0.0850 * 1.0223)+(0.0374 * 0.9862)+ \\
+(0.0076 * 1.0311)+(0.0032 * 1.0353)+0.1085=1.029
\end{gathered}
$$

Table 5 - Values of the indices $\mathbf{I}_{\mathrm{cops}}, \mathbf{I}_{\mathrm{cvnd}}, \mathbf{I}_{\mathrm{cpo}}, \mathbf{I}_{\mathrm{ct}}, \mathbf{I}_{\mathrm{cpv}}$

\begin{tabular}{|c|c|}
\hline Index & Value \\
\hline $\mathrm{I}_{\text {cops }}$ & 1.0200 \\
\hline $\mathrm{I}_{\mathrm{crnd}}$ & 1.0311 \\
\hline $\mathrm{I}_{\mathrm{cpo}}$ & 1.0353 \\
\hline $\mathrm{I}_{\mathrm{ct}}$ & 0.9862 \\
\hline $\mathrm{I}_{\mathrm{cpv}}$ & 1.0223 \\
\hline
\end{tabular}

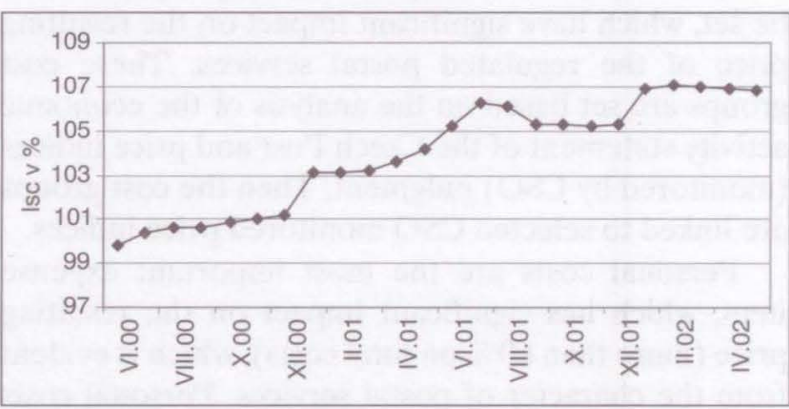

Figure 1 - Development of index Isc within the hypothetical monitored period

Note: $100 \%$ represents the average value of the year $n-1$

The resulting value of index $I_{i}$ is 1.029 , which means that the prices of regulated services should increase (thanks to the inflation of the input variables) only by $2.9 \%$ within the regulated period. Moreover, the resulting price of the tariff basket is reduced by the value of motivation factor $X$ (see Equation 1). In case of $X=1$ setting (this value is very favourable for the Czech Post), the new total price of tariff basket $P_{1}$ should increase only by $2 \%$ (compared to the $P_{0}$ price).

There is a possibility to compare this value with the real price increase of the Czech Post regulated services within the regulated period, which was $18.5 \%$ (standard letter items). Although there was a relevant requirement to invest into the sorting machines, means transport etc. (because of the Czech Post underdevelopment in comparison to other postal operators from the developed EU states), it is evident that the real price increase of the regulated services was too high and most importantly this price increase was not based on the real cost calculation. This is the reason, why it is useful to do an audit by an independent auditory company (also mentioned in Chapter 4.4) in order to verify the initial $P_{0}$ price prior to the beginning of proposed price control implementation.

There is a possibility to tighten the price control up by one extra fixed price determination for the most common weight step $(20 \mathrm{~g})$ of letter items basket (also see Chapter 4.2).

Concretely, the equation should be as follows:

$p_{1}=p_{0} *\left(\frac{100+K}{100}\right)$ 
where:

$p_{0}, p_{1}$ - original and the new price of standard letter items (up to $20 \mathrm{~g}$ ),

$K$ - fixed percentage of price growth of the standard letter items during the regulated period (for example $3 \%$ ).

Since there is general effort to reduce control procedures, the application of this instrument should be considered very carefully.

Finally, we should add that in case of application this price control method in order to set the maximum allowed price growth of the letter items basket in the current period, one of the time series extrapolative method for indices $I_{s o} I_{c o p s} I_{c p v}, I_{c b}, I_{c v n d}, I_{c p o}$ calculation has to be used.

\section{CONCLUSION}

It is evident that the price control of the Czech postal sector is well-founded in the current situation. However, the method of price control of the domestic postal services under the control used in the Czech postal sector is not suitable. A more effective and more transparent method of price control of these services would be the price-cap method which is already used in several EU member states. There is the need to consider the necessary scope of that price control, i. e. which services should be regulated before the application of this method of price control.

The calculated price increase of the tariff basket (letter items) was evidently under the level of real price increase of the Czech Post regulated services within the hypothetical control period from the past (but it is also valid for this time), which just shows the missing linkage of the current price control with costs.

Finally, it is evident that the proposed price control model, based on the objective data input, is so transparent that the regulated company will not lie at the mercy of NRA and its political price plans, as opposed to the current price control method.

Ing. LIBOR ŠVADLENKA, Ph.D.

E-mail: libor.svadlenka@upce.cz

Ing. ALEXANDER CHLAÑ, Ph.D.

E-mail: alexander.chlan@upce.cz

Univerzita Pardubice, Dopravní fakulta Jana Pernera

Studentská 95, 53210 Pardubice, Česká republika

\section{ABSTRAKT}

\section{PRINCIPY NAVRHOVANÉHO MODELU CENOVÉ REGULACE SEKTORU POŠTOVNÍCH SLUŽEB ČESKÉ REPUBLIKY}

Článek se zabývá regulací sektoru poštovních služeb. Vychází z teorie regulace a ospravedlnuje regulaci právě tohoto sektoru. V rámci cenové regulace vychází článek z požadavků
Směrnice 97/67/EC kladených na cenovou regulaci sektoru poštovních služeb, definuje jednotlivé typy cenové regulace, které by mohly nahradit v současné dobè uplatñovanou neefektivní cenovou regulaci českého poštovního sektoru (zejména pokud jde o vnitrostátní listovní zásilky) a navrhuje efektivnějš́ metodu cenové regulace. Článek následně detailně popisuje tuto nově navrhovanou metodu cenové regulace. Popisuje konstrukci navrhovaného modelu cenové regulace vycházejicího z principu price-cap a tarifni formule RPI-X a následně se zaměřuje na kvantitativní vyjádření modelu. Aplikace navrhovaného modelu je uskutečněna pro hypotetické období v minulosti (za účelem možnosti porovnáni se stávajicí metodou cenové regulace) a pro tarifní koš listovnich zásilek.

\section{KLÍČOVÁ SLOVA}

regulace, ceny, poštovní služby, cenový strop, Česká pošta, model

\section{REFERENCES}

1. $\S 2$, Act of the Czech Republic No. 29/2000 Coll., on postal services as amended

2. $\S 1$, par. 6 Act of the Czech Republic No. 526/1990 Coll., on prices

3. $\S 2$ par. 1 and $\S 2$ b par. 1 Act of the Czech Republic No. 265/1991 Coll., on the field of activity of state administration bodies of the Czech Republic

\section{LITERATURE}

[1] P. A. Samuelson, W. D. Nordhaus: Economy, Second Edition, Prague: Publishing house Svoboda, 1995, 1011 p. ISBN 80-205-0494-X.

[2] V. Garaj: Econometric simulation, Bratislava: Economic University in Bratislava, 1992, ISBN 80-225-0458-0 .

[3] M. Giulietti, C. W. Price: Incentive Regulation and Efficient Pricing: Empirical Evidence [online]. Coventry: Centre for Management under Regulation, Warwick Business School, 2000, No. 00/2. [cit. 2003-02-12] Available from:

< http://users.wbs.warwick.ac.uk/cmur/publications/ research_papers.htm\#2000>, ISSN 1369-0450.

[4] Price Control Review for Consignia plc [online], Postcomm, 2001, [cit. 2003-10-28]. Available from: $<$ http://www.psc.gov.uk/index $2 . h t m l>$.

[5] C. Schwarz-Schilling et al.: Pricing Schemes in Liberalized Postal Markets, In Competition and Universal Service in the Postal Sector. [online] Second conference. Toulouse, December 6-7, 2001, Available from: $<$ http://www.idei.asso.fr/Commun/Conferences/ Autres\%20Conf/Decembre2001/Papers/ schwarz-S.pdf $>$.

[6] L. Švadlenka: Quantitative Expression of Proposed Price Control Model of Czech Post, Transport and Communication, 2005, n. 1. FPEDAS, University of Zilina 2005. ISSN 1336-7676. 
[7] L. Madleňáková: . In Perner's contact 2003, DFJP University of Pardubice. Pardubice: University of Pardubice, 2003, pp. 18-25, ISBN 80-7194-524-2.

[8] J. I. CAMPBELL et al.: Main Developments in the European Postal Sector [online], WIK consult, 2004, [cit. 2006-05-04], Available from:

$<$ http://ec.europa.eu/internal_market/post/doc/ studies/2004-wikfinal_en.pdf >.
[9] Act of the Czech Republic No. 141/2005 Coll. by which the full statutory text of Act of the Czech Republic No. 29/2000 Coll., on postal services

[10] Act of the Czech Republic No. 526/1990 Coll., on prices 